811.163.41'374=161.1

378.147::811.163.41'243(470)

811.163.41'373.42:811.161.1'373.42

https://doi.org/10.18485/msc.2018.47.1.ch45

Ирина Ј. ИВАНОВА*

Московский государственный университет

им. М.В. Ломоносова

Факультет иностранных языков и регионоведения

Москва

Москва
Оригинални научни рад

Примљен: 30. 09. 2017.

Прихваћен: 27. 12. 2017.

\title{
РЕЧНИЦИ У НАСТАВИ СРПСКОГ ЈЕЗИКА КАО СТРАНОГ НА МГУ
}

\begin{abstract}
Као професор који више од 40 година предаје српски језик на Историјском, Географском факултету и Факултету страних језика и регионалних истраживања (ФИЈАР) морам да изразим захвалност ауторима речника српског језика који су незаобилазан елеменат у настави. Док се у почетној етапи могу користити уџбеници који садрже своје мини речнике, касније, приликом самосталног рада на превођењу оригиналних текстова, студенти морају наћи одговарајући превод у већем речнику који садржи детаљне граматичке и семантичке податке. То су пре свега „Српскохрватско-руски речник” (1970) чији је аутор И. И. Толстој и „Руско-српскохрватски речник” (1988), уредник Б. Станковић. Приликом превођења полисемичне речи јавља се проблем избора одговарајућег значења. Ту може доћи до забуне пошто многи студенти не праве разлику између различитих значења исте речи. У том погледу може бити интересантан годишњи рад једног од студената ФИЈАР који је упоредио обим значења 50 српских именица и њихових руских еквивалената (према првом значењу речи) користећи за ту анализу Речник Матице српске и Мали речник руског језика РАН.

Кључне речи: речник, српски језик, српскохрватско-руски речник, превођење, настава, интернационална лексика, полисемија.
\end{abstract}

Моје искуство као професора српског односно српскохрватског језика укључује наставу на Факултету страних језика и регионалних истраживања, као и језика струке на Историјском и Географском факултету. И у једном и у другом случају у процесу наставе велику улогу играју речници српског језика.

За студенте последња два факултета главни задатак је самостални превод оригиналних српских стручних текстова, што захтева непосредан рад

*iva53@inbox.ru 
студента са српско-руским речником. Такав приручник за нас је „Српскохрватско-руски речник” који је саставио И. И. Толстој (Толстој 1970). Овај речник укључује 54 хиљаде речи. Прво његово издање појавило се 1957. године, то је био први српскохрватско-руски речник, објављен у Совјетском Савезу. И. И. Толстој у предговору наглашава да су „раније у Русији били познати само „Српско-руски речник” П. Лавровског, објављен 1870, и „Диференцијални српско-руски речник” Л. А. Мичатека, који је изашао из штампе 1903. године” (Толстој 1970: 7). У предговору такође стоји да се „заснива на лексичкој грађи савременог српскохрватског књижевног језика. У речник су унете нове друштвенополитичке и техничке речи, као и нове речи из свакодневног живота" (Исто: 7). Речник садржи и старију лексику која је широко заступљена у класичној књижевности. Последња околност га чини погодним извором информација за студенте историјског факултета у чијим се стручним текстовима често употребљавају речи које су ретке у данашњој употреби. Речник садржи попис географских имена и њихов превод на руски језик. Ово издање које је потребно сваком појединцу који учи српски језик, срећом, доступно је на интернету, тако да га наши студенти могу преузети и користити у свакој прилици.

Речник о којем говоримо посебно је важан за оне који уче српски језик због граматичких података који се наводе за сваку реч. Тако, акценатске или фонетске промене до којих долази у индиректним падежима именице дају се у облику генитива на другом месту иза облика номинатива. Уз инфинитив стоји облик првог лица једнине презента, као и одговарајући свршени / несвршени глагол.

Овај речник због свог релативно малог обима садржи мали број тзв. интернационалне лексике и зато је мање користан за проналажење значења речи преузетих из страних, углавном европских језика, на које студенти често наилазе у историјским и политичким текстовима. То су такве речи као што су евентуалан - рус. вероятный, функција - рус. должность (у Толстојевом речнику налазимо превод који звучи као и српска реч - функиия, али нема значење дужност, положсај). Навешћемо још неке од таквих речи: партикуларизам - политическая раздробленность, локализам - местничество, стратум - социальный слой, фаворизовати - ставить в исключительное положение, субверзиван - подрывной, агитација - агитационная поездка, модалитет - модификаџия, диспозитив - введение, промулгација - обнародование, новелирати - вводить, деликвенција - преступление, експонирати се - проявлять себя и друге. Студенти Географског факултета имали су проблема са преводом речи крашки - карстовый, салинитет - соленость, алогени токови - исчезающие реки и томе слично.

У таквом случају се јавља потреба да се преводилац обрати речницима страних речи као што су „Лексикон страних речи и израза” Милана Вујаклије (Вујаклија 1991) и „Велики речник страних речи и израза” Ивана Клајна и Милана Шипке (Клајн/Шипка 2012). Српски речници страних речи се не продају у Русији, али се на интернету може наћи Вујаклијин речник у PDF формату. Студенти су такође у могућности да се, у прилици када не могу 
наћи превод неке речи, обрате мени као наставнику, тако да заједно нађемо решење. На располагању им је и речник Братољуба Клаића „Рјечник страних ријечи и израза" (Клаић 1980) из моје кућне библиотеке.

Новији српско-руски речници Матије Даутовића (Даутовић 2002) и Радослава Бошковића (Бошковић 2013) студентима у нашој земљи нису доступни за свакодневну употребу: нема их у продаји, нити су доступни преко интернета.

Нажалост, данас студенти често прибегавају трагању за преводом речи користећи се онлајн преводиоцима који често дају немогуће еквиваленте и само збуњују кориснике. При томе треба узети у обзир да иначе интернет пружа велике могућности за проверу значења речи и колокација у којима оне учествују.

За самосталан рад студената на превођењу текстова с руског језика на српски најкориснији је „Руско-српскохрватски речник” у редакцији Богољуба Станковића (Станковић 1988), први пут објављен 1988. године у едицији „Матице српске” и издавачке куће „Русский язык”, Нови Сад - Москва. Речник садржи 52 хиљаде лексичких јединица. Укључује речи и синтагме, представљене у руској класичној и савременој лепој књижевности, разговорну, друштвено-политичку лексику, фразеологију. У њему се нашло место и за терминологију. Речник одликује велики број синтагми „које илуструју употребу руских речи и њихових српскохрватских еквивалената" (Станковић 1988: 5). Садржи и обимну листу географских имена. Речник је доступан на интернету.

Предавач треба да научи студенте да је преводилачки посао доста тежак и за њега треба имати стрпљења, али је на другој страни интересантан и узбудљив и подсећа на решавање загонетака. За студента сложеност самосталног превођења уз помоћ речника изазвана је низом узрока. Пре свега, то је потреба да се закључи из граматичког и лексичког контекста о којој се врсти речи ради, да се успостави њен првобитни облик, као што су номинатив именице, инфинитив глагола итд. Најзад, треба изабрати једно значење између неколико наведених у речнику.

Дешава се да су млади преводиоци сувише лењи да провере значење кратке речи: речце или везника. Они једноставно не могу да верују да таква ситница може да промени значење целе реченице. Зато приликом провере самосталног превода професор треба да пружи помоћ студенту и да они заједно активно користе речник. Веома је важно да се покаже у речнику у којој мери може да се промени превод реченице у зависности од значења тако кратке речи као што је речца, односно везник да, за коју је већина руских студената сигурна да одговара руском саставном везнику $u$.

Студенти често нису у стању да изаберу за превод речи право значење ако их је више наведено у речничкој одредници. Понекад се то може десити уколико речник не садржи тачно онај превод који би био потребан за конкретан текст. Зато је врло важно да наставник објасни и више пута понови да речник не садржи обавезно превод него описује појам. Задатак самог тумача је да пронађе тачну реч или израз који би био синоним наведеном у речничкој одредници и који би стао у текст превода као неопходан део слагалице. 
Са друге стране, понекад полазници не осећају разлику међу различитим значењима и нијансама значења једне речи. Због тога користе прво значење, верујући да су сва остала његови синоними, на које се не мора обраћати пажња.

Један од студената Факултета страних језика и регионалних истраживања, Алексеј Струин, коме сам била ментор, написао је дипломски рад који доприноси превазилажењу таквог површинског погледа на значење речи приликом превођења. Задатак његовог истраживања било је упоређивање вишезначних речи у српском и руском језику.

Аутор студије упоредио је 50 парова речничких одредница из Речника Матице српске (РМС 1967) и Речника руског језика РАН у четири тома (РPJ 1999) с циљем да утврди у којој се мери поклапају значења српских именица и њихових руских еквивалената. Речи би се одређивале као еквивалентне кад би имале једно заједничко значење, при том се полазило од првог значења српске речи. Током рада аутор је наилазио на одређене потешкоће. У неким случајевима није било једноставно одредити да ли се ради о истом значењу пошто је логика дефиниција на руском и српском понекад различита.

Студија је показала да се између одабраних именица у потпуности поклапају значења само четрнаест речи. То су каверна - рус. каверна; кадар - рус. $\kappa a \partial p ы$ и кадр; казамат - рус. каземат; камелеон - рус. хамелеон; каос - рус. $x a о c$; каприц - рус. каприз; карактеристика - рус. характеристика; каша - рус. каша; калорија - рус. калория; каљуга - рус. грязь, камара - рус. куча; капитал - рус. капитал; капсула - рус. капсула; караван - рус. караван.

Осталих 36 речи се разликују по обиму значења. Навешћемо неколико примера.

Српска реч када има два значења: 1) суд за купање, 2) каца. У руском језику им одговарају две именице - ванна и кадка.

Српска лексема канделабар се поклапа са руском канделябр у једном значењу - велики богато украшен свећњак са неколико огранака за свеће или жаруље. Друго значење српске речи - стуб за уличну или другу расвету - руском еквиваленту недостаје.

Српска именица капацитет и руска мощность имају три заједничка значења: 1) способност да се што учини, оствари, снага, моћ, јачина; 2) просторност, обујам, запремина, носивост; 3) способност неког тела да у себе прими електрицитет, топлоту. Српска реч поседује још једно значење - човек великих, изузетних способности, познат и признат стручњак. Речник илуструје ово значење примером из О. Давича: Он је ненормално велики радни капацитет.

Српски турцизам капија и руска реч ворота поклапају се у два значења: 1) улазна врата... у градским бедемима, на... згради, дворишту и сл.; 2) тачно обележен и брањен простор на игралишту у који се гађа лоптом у фудбалу, хокеју и сл. Српска реч има још једно значење, то је војни термин: стратешки важно место за даље напредовање. Руски еквивалент исто има још једно значење, то је медицински термин: место уласка и изласка из било ког органа крвних и лимфних судова. 
Српска позајмљеница кабл (кабел, хол. kabel) поклапа се у једном свом значењу - херметички изолиран електрични вод за подземне и подводне линије - са руском једнозначном именицом кабель. Два друга значења одговарају двема руским именицама: 2) бродски конопац од челичних жица - руска реч канат; 3) мера за даљину - руска именица кабельтов.

Српска именица кажипут одговара руском еквиваленту указатель у једном значењу - 1) путоказ - и има још два значења: 2) човек или ито друго као... узор у жсивоту; 3) кажипрст. Руска реч указатель има још једно значење - приручник или референтна листа на крају књиге.

Што се тиче српске именице кадар, истраживач долази до закључка да су у речнику Матице српске уједињена у једној одредници три значења која у суштини одговарају двема различитим речима: 1) сва лица обухваћена једном службом, струком, организацијом; 2) обавезна мирнодопска војничка служба и 3) део филма, који камера сними одједном. Последње значење није повезано са прва два и требало би да се третира као посебна реч. Дакле, прва два значења одговарају руској именици pluralia tantum кадры и последње - именици кадр.

Српска реч карта поклапа се с руским еквивалентом карта у четири значења: 1) мапа; 2) картон у облику правоугаоника, од којих је састављен сноп играћих карата које се између себе разликују по боји, по фигурама и сл.; 3) формулар, бланкет (болничка карта); 4) јеловник. Српска именица има још 4 значења која се не подударају са руским: 5) картање; 6) поштанска дописница, раздледница; докуменат којим се посведочава припадност каквој организацији; 7) докуменат којим се посведочава право коришћења чега (за кино, повратна, возна).

Српска позајмљеница из грчког канон поклапа се с руским еквивалентом у шест значења: 1) правило прописано од највише црквене власти, догма; 2) правило каквог учења или кьижевног правца; 3) песма у част празника или свеца; 4) списак религиозних књига, признатих од стране црквене власти; 5) у католичкој цркви трећи, главни део мисе, а у православној сваки прописани црквени обред; 6) вичегласни састав у којем мелодију почетног гласа понављају један за другим гласови на различитим интервалима. Једно значење - врста великих речи - руском еквиваленту недостаје.

Основна вредност овог истраживања састоји се у томе да после обављеног рада њен аутор може добро да сагледа каква је структура речничке одреднице, чему служе примери наведени у њој, у којој се мери једно значење исте речи може разликовати од другог. Сличан задатак, наравно мањег обима, добијају и други студенти пре него што почну да се баве превођењем. 


\title{
ЛИТЕРАТУРА
}

Бошковић 2013: Р. Бошковић, Српско-руски речник, Београд: Јасен. Вујаклија 1991: M. Vujaklija, Leksikon stranih reči i izraza, Beograd: Prosveta. Даутовић 2002: M. Dautović, Hrvatsko-ruski rječnik, 1-2, Zagreb: Školska knjiga. Клаић 1980: B. Klaić, Rječnik stranih riječi, Zagreb: Nakladni zavod. Клајн/Шипка 2012: I. Klajn, M. Šipka, Veliki rečnik stranih reči i izraza, Novi Sad: Prometej.

PPJ 1999: Словарь русского языка, 2, Москва: РАН.

PМC 1967: Речник српскохрватскога књижевног језика, 2, Нови Сад, Загреб: Матица српска, Матица хрватска.

Станковић 1988: Русско-сербскохорватский словарь, Москва, Нови Сад: Русский язык, Матица српска.

Толстој 1970: И. И. Толстой, Сербскохорватско-русский словарь, Москва: Советская энциклопедия.

\author{
Ирина Й. Иванова
}

\section{СЛОВАРИ ПРИ ОБУЧЕНИИ СЕРБСКОМУ ЯЗЫКУ КАК ИНОСТРАННОМУ В МГУ}

\section{Резюме}

Являясь более 40 лет преподавателем сербского / сербохорватского языка на историческом, географическом факультетах и факультете иностранных языков и регионоведения МГУ, я должна выразить благодарность авторам словарей сербского языка, которые являются неотьемлемым элементом учебного процесса. Хотя на начальном этапе обучения можно использовать имеющиеся в учебниках мини-словари, позже, при самостоятельной работе над переводом оригинальных текстов, студенты должны найти соответствующий перевод в более крупном словаре, содержащем подробные грамматические и семантические данные. Это прежде всего „Сербскохорватско-русский словарь”, составителем которого был И. И. Толстой, и „Русскосербскохорватский словарь” под редакцией Б. Станковича. При переводе многозначного слова возникает проблема выбора правильного значения. К сожалению, студенты часто не различают разные значения одного и того же слова. В этом отношении важна дипломная работа одного из студентов ФИЯР, в которой сопоставляется объем значений пятидесяти сербских существительных и их русских эквивалентов (в соответствии с первым значением слова). В ходе исследования использовались Словарь Матицы сербской и Малый словарь русского языка РАН.

Ключевые слова: словарь, сербский язык, сербскохорватско-русский словарь, перевод, преподавание, интернациональная лексика, полисемия. 